\title{
Fine Structure of the Reticular Cells in the Rat Spleen, with Special Reference to Their Fibro-Muscular Features
}

\author{
Hiroaki SAITo
}

Received March 3, 1977

\begin{abstract}
Summary. Reticular cells in the rat spleen were studied with the electron microscope. Besides well developed cisterns of the granular endoplasmic reticulum and the Golgi complex like in fibroblasts, the reticular cells contain small bundles of microfilaments, dense bodies and hemidesmosomes as in the smooth muscle cell. Based on these cytological characteristics, it is suggested that the reticular cells are fibro-muscular in nature, and they may play roles in fibrogenesis as well as in regulation of the blood flow by their contraction in the splenic reticular tissue.
\end{abstract}

The correlation of fine structure to function in the spleen, including the nature of the reticuloendothelial system in this organ, has been a subject of much speculation and controversy. This is mainly due to the insufficient knowledge of the architecture and fine structure of cellular elements of the splenic tissue.

A number of morphological studies on the reticular cells have dealt with their relation to the extracellular reticulum and have discussed their possible functions of fibrogenesis (Simon and Pictet, 1964; Moore et al., 1964; Pictet et al., 1969). Little attention, however, has been paid to what structures may participate in the regulatory mechanism of circulation in the organ as contractile cell elements, though a number of smooth muscle cells have long been known in the classic capsulo-trabecular system (BLOom and FawCETt, 1968).

Recently, De BRUYN and Chо (1974) have reported the presence of microfilaments as contractile elements in the splenic sinus wall. These microfilaments, similar to thin myofilaments of smooth muscle cells, have been detected in a wide variety of cell types and strongly suggest a possibility that non-muscular cells may play a role in contraction of tissue (IshiKawa et al., 1969; Nachmias et al., 1970; Pollard and Ito, 1970; Wessels et al., 1971; Yamada et al., 1971).

The present paper dealing with the fine structure of the reticular cells of the rat spleen shows the existence of microfilaments, dense bodies and hemidesmosomes in the cytoplasm and discusses the possibility that some reticular cells might be fibromuscular in nature and contribute to a contractile mechanism in circulation regulation, in collaboration with major contractile elements in the capsulo-trabecular system.

\section{Materials and Methods}

Five adult normal Wistar rats ranging from 200 to $480 \mathrm{~g}$ in body weight were used in this study. The spleen was removed under pentbarbitrate anesthesia and minced into small pieces in a cold fixative of $2 \%$ glutaraldehyde in cacodylate buffer at $\mathrm{pH}$ 7.4. Tissue blocks were fixed in glutaraldehyde solution at $4^{\circ} \mathrm{C}$ for $2 \mathrm{hrs,}$ 


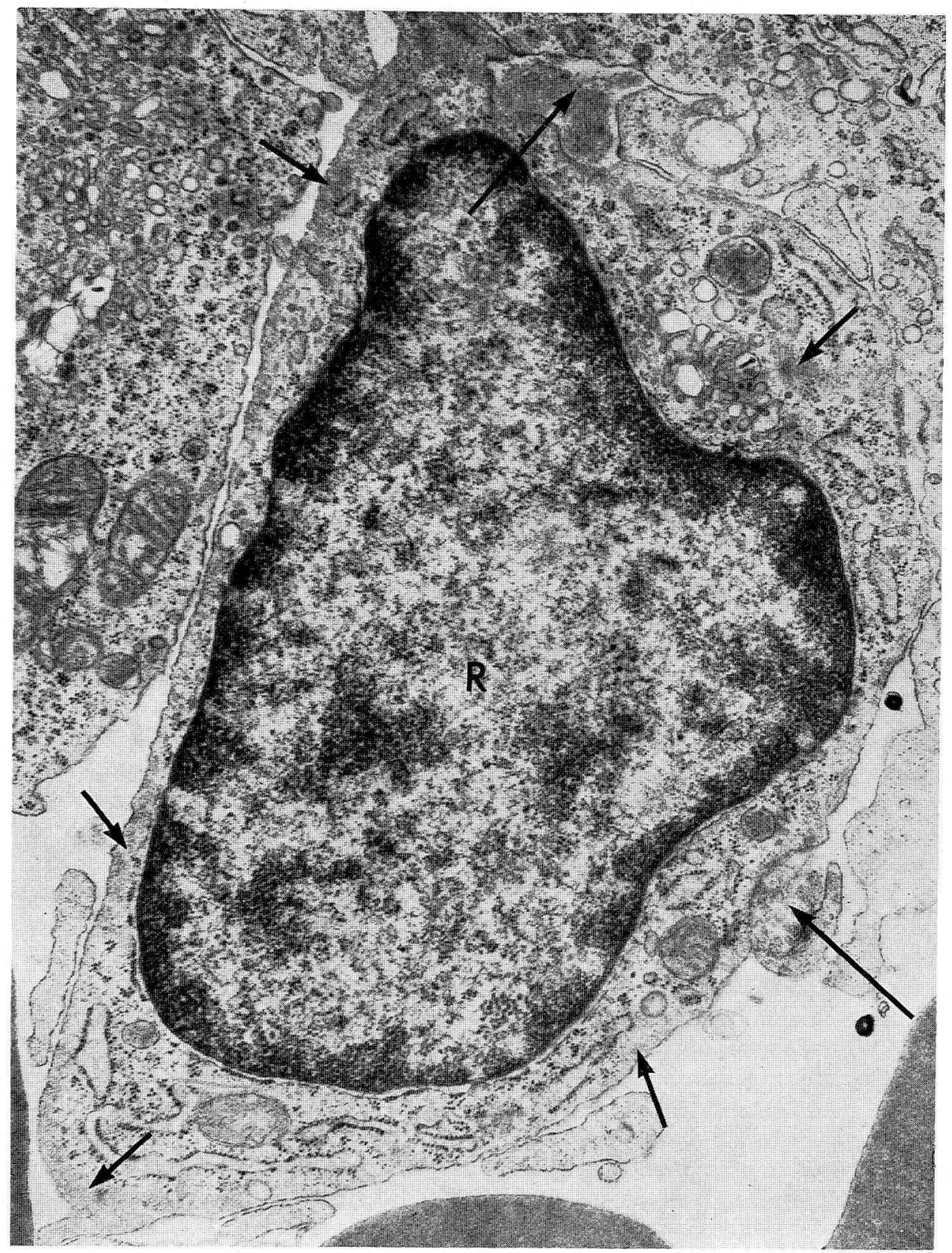

Fig. 1. Typical reticular cell $(R)$ in the red pulp associated with two sections of the extracellular reticulum (long arrow). Everywhere in the cytoplasm small bundles of fine filaments are observed (short arrow). The upper extracellular reticulum consists of a basal lamina-like material. The lower one is incompletely enclosed by a cytoplasmic process and the reticular cell. $\times 20,000$ 
washed in buffer and postfixed in $1 \%$ osmium tetroxide in the same buffer for $1 \mathrm{hr}$. They were then dehydrated through a series of graded concentrations of cold ethanol, transferred into propylene oxide and embedded in an Epon-Araldite mixture. Thin sections were obtained on a Porter-Blum MT-1 ultramicrotom with glass knives, stained with $2 \%$ ethanol solution of uranyl acetate (W ATson, 1958) for 20 min followed by lead citrate (VENABLE and MoOSEKER, 1971) for $10 \mathrm{~min}$ and examined with a Hitachi HS-8 electron microscope. Thick sections obtained from the same blocks were stained with toluidine blue for light microscopy. Another fixation and staining method with the use of tannic acid (FUTAESAKu et al., 1972) was employed for staining elastic components in the extracellular reticulum.

\section{Results}

The sustentacular architecture of the spleen is a three-dimensional framework of reticular tissue enclosed within a capsulo-trabecular system of dense connective tissue, which is subdivided into the red pulp, white pulp and the marginal zone. The reticular tiesue is made up of reticular cells and extracellular reticulum. The latter is sandwiched or enclosed by thinned flaps or the body of the former cells (Fig. 6, 8). The extracellular components of the reticular tissue are composed of collagenous fibrils (Fig. 4, 8, 9), elastic fibers associated with microfibrils (Fig. 7, 8), and an accumulation of moderately dense materials which have a texture quite similar to the basal lamina (Fig. 1,8). The proportion of these components varies with thickness of the extracellular retculum. Basal lamina-like material which is finely fibrillogranular in texture shows an irregular mass in places and occasionally forms a sheet of feltwork apposed to the plasma membrane of the reticular cell with a less dense layer 200 to $300 \AA$ in width (Fig. 5). Elastic fibers appear moderately dense in the present specimen preparation and are intensively stained by tannic acid. They are frequently surrounded with more or less microfibrils (Fig. 11). They are found more frequently in the white pulp and the marginal zone than in the red pulp.

The reticular cells have several long slender cytoplasmic processes closely associated with extracellular reticulum fibers which extend to contact the processes of neighboring cells. The reticular cells, together with the fibers, thus, form the framework of the tissue. The intercellular space of adjoining cells is about 200 to $400 \AA$ wide (Fig. 1); in some occasions two plasma membranes are closely apposed resembling the gap junction (Fig. 6). The nucleus of the reticular cell contains one or two nucleoli and heterochromatin accumulation along the nuclear envelope (Fig. 1, 7). Nuclear inclusions of various sizes are often found which are quite similar in appearance to the "nuclear bodies" reported previously (BouteIlle et al., 1967; BRooKs and Siegel, 1967; Buttner, 1968) (Fig. 2). They consist of an accumulation of osmiophilic small particles which are identical in texture to karyosomes, surrounded by a finely fibrillar cortical band. The functional significance of these bodies is unknown.

The granular endoplasmic reticulum and the Golgi complex are well developed in the cytoplasm. It is noticeable that the tubular or saccular cisterns of the granular endoplasmic reticulum contain more or less flocculent materials in contrast to the empty-looking Golgi vacuoles and vesicles (Fig. 3, 8). A small number of mitochondria and free ribosomes are scattered throughout the cytoplasm. Lysosomal particles, multivescular bodies, lipid droplets and probable phagosomes are found frequently. Microtubules about $250 \AA$ in diameter are developed in the cytoplasm, 

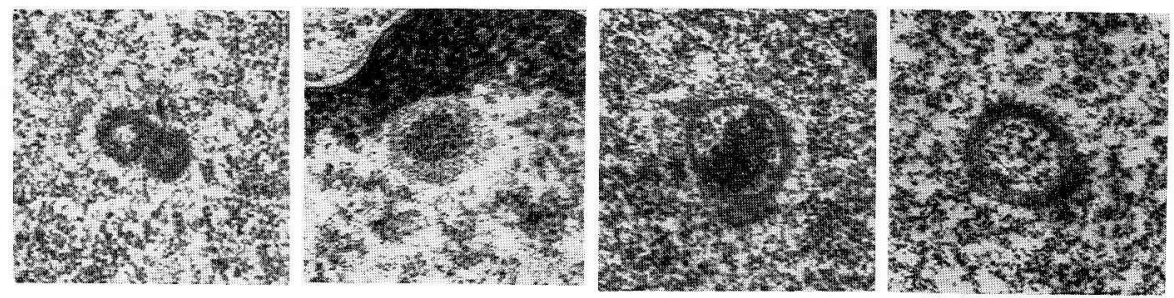

Fig. 2. Several types of nuclear body. $\quad \times 50,000$

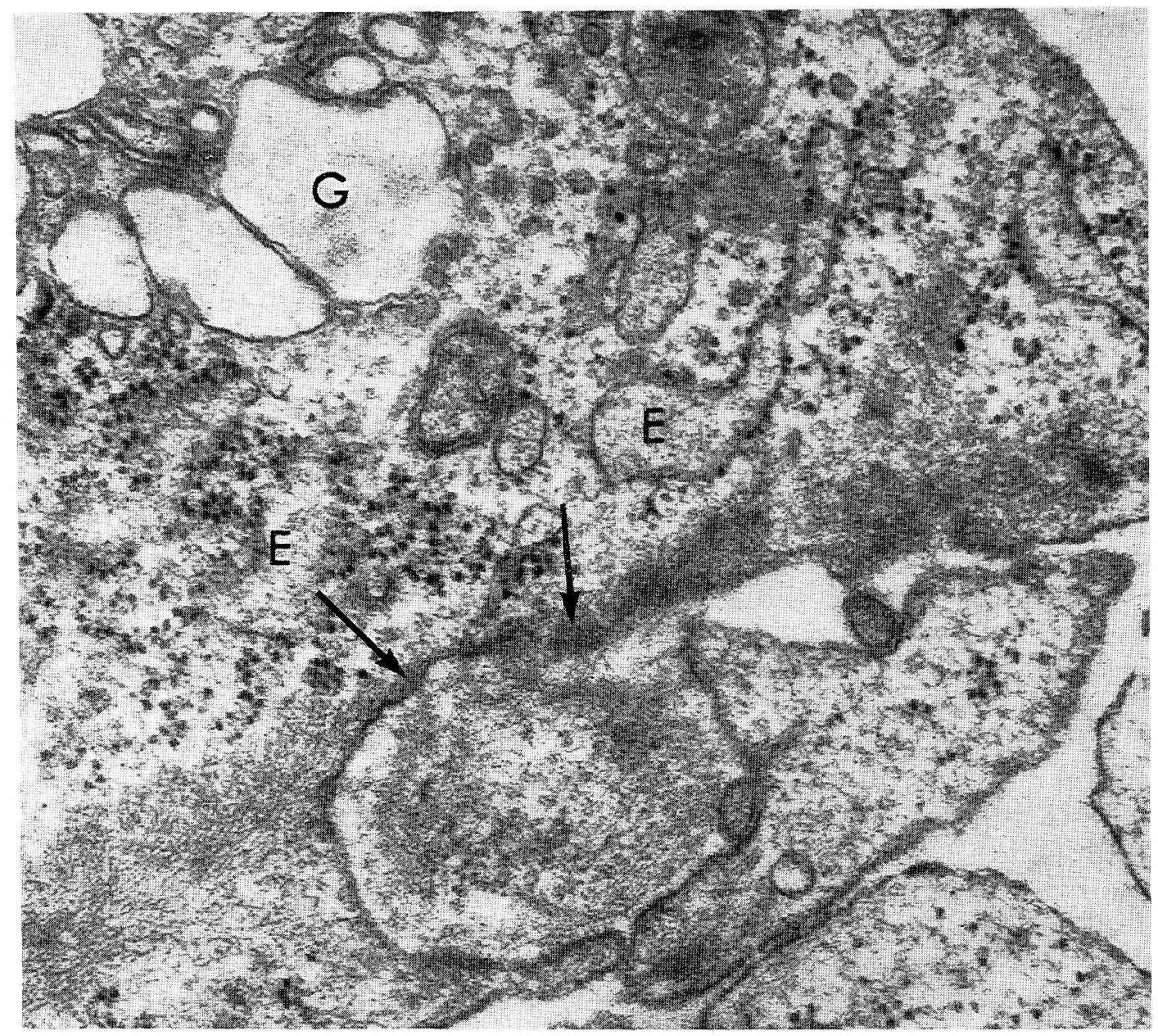

Fig. 3. Reticular cell processes in the red pulp. Bundles of filaments insert the plasma membranes to show dense areas reminiscent of hemidesmosomes (arrow). Granular endoplasmic reticulum $(E)$ contains flocculent material, while Golgi vacuoles are empty $(G) . \quad \times 38,000$

especially in the peripheral regions (Fig. 6, 8).

A peculiar feature of the reticular cell cytoplasm is the presence of filamentous structures and the hemidesmosomes. The cytoplasmic filaments are composed of a homogeneous population of filaments 40 to $50 \AA$ in diameter and form small bundles (Fig. 1, 6-10). These filaments appear to insert into either the hemidesmosomes at the plasma membrane (Fig. 3, 6, 8), or the dense bodies intervening in the course of 

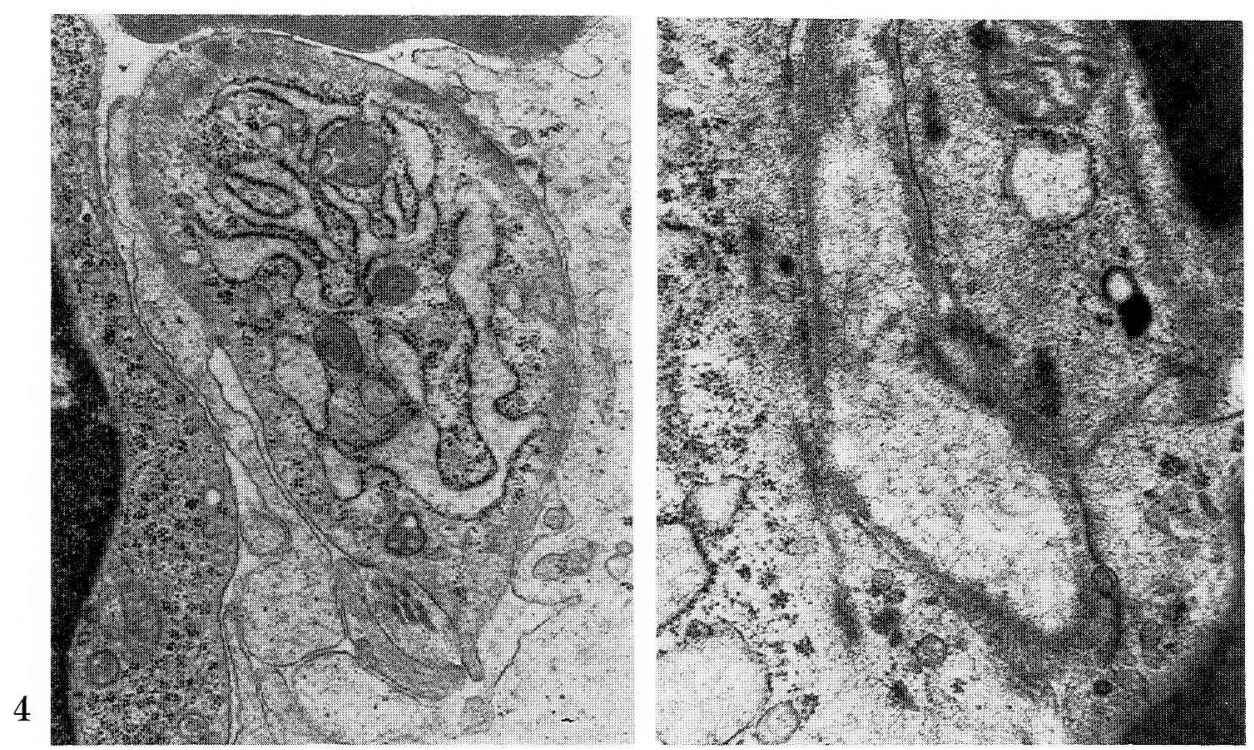

Fig. 4. Reticular cell process in the red pulp associated with the extracellular reticulum containing collagenous fibrils shows well developed endoplasmic reticulum. $\times 15,000$

Fig. 5. Basal lamina-like material in the extracellular reticulum. $\times 20,000$

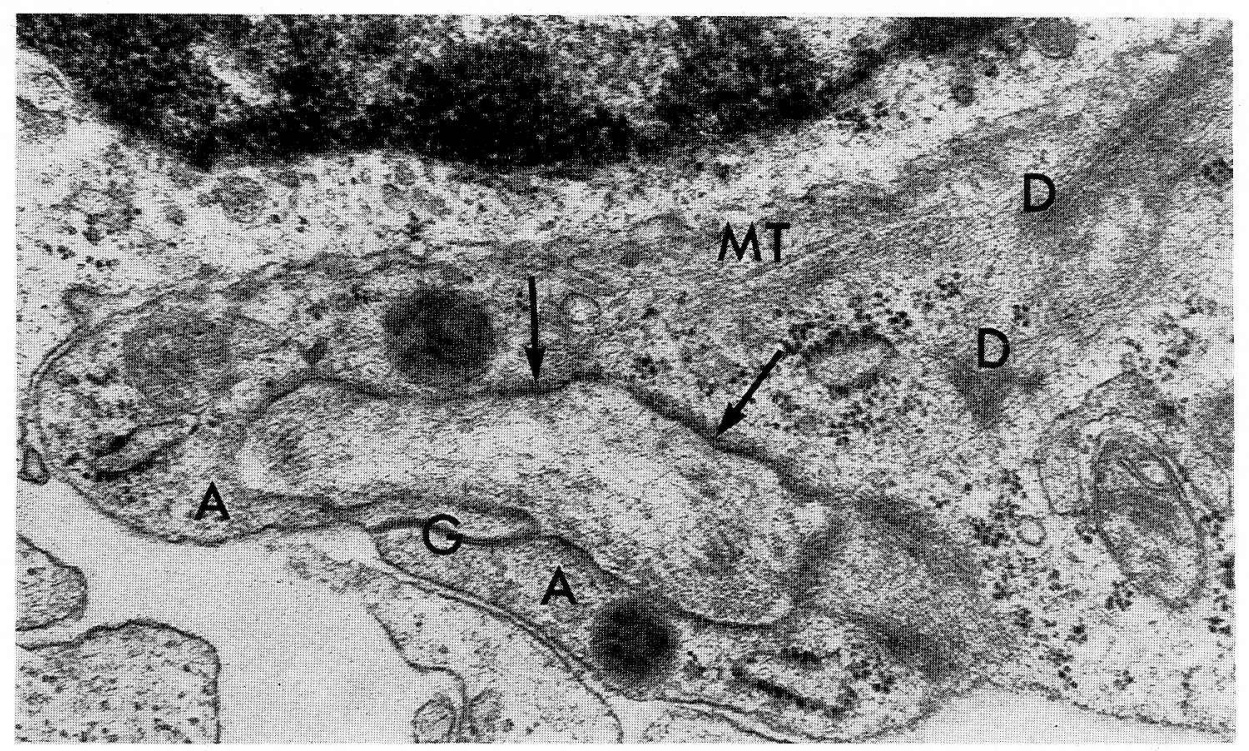

Fig. 6. Cytoplasmic process of the reticular cell in the red pulp. Bundles of filaments are seen and among them dense areas $(D)$ are present. The cell margin facing the extracellular raticulum shows electron dense areas reminiscent of hemidesmosomes (arrow). Between cytoplasmic arms $(A)$ which enclose the extracellular reticulum, gap-junctional device $(G)$ is observable. $M T$ microtubule. $\times 30,000$ 
H. Saito:

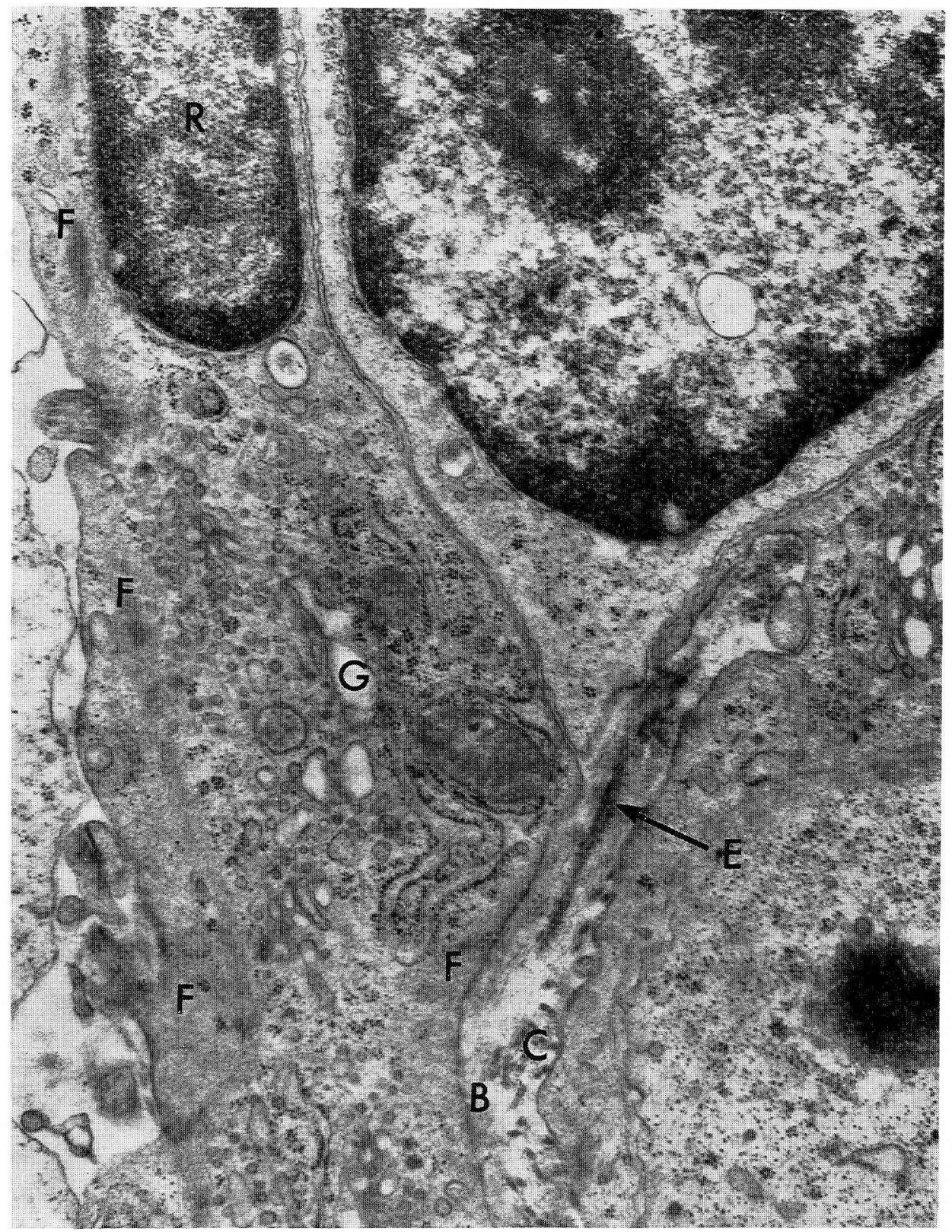

Fig. 7. Reticular cell $(R)$ in the marginal zone. The Golgi complexes $(G)$ are well developed. Filaments are faintly observed throughout the cytoplasm $(F)$. In the extracellular reticulum, all the elements of connective tissue stromas, such as collagenous fibrils $(C)$, elastic fiber $(E)$ associated with microfibrils and basal lamina-like material $(B)$ are found. $\times 28,000$ 


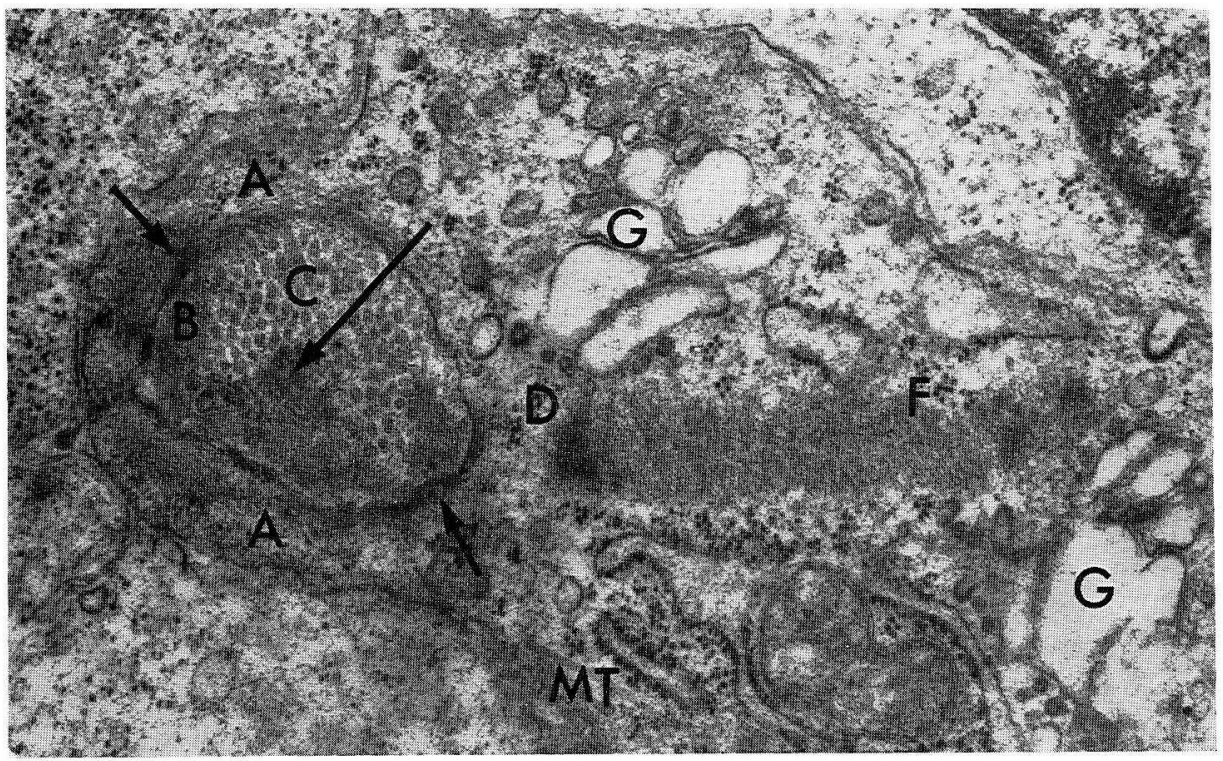

Fig. 8. Reticular cell process in the white pulp containing bundle of filaments $(F)$. At the end of this bundle, dense area $(D)$ is present. In the cytoplasmic arms $(A)$ which enclose the extracellular reticulum containing elastic fiber associated with microfibrils (long arrow), collagenous fibrils $(C)$ and basal lamina-like material $(B)$, fine filaments are rather gathering beneath the plasma membranes to show dense areas reminiscent of hemidesmosomes (short arrow). Golgi vacuoles $(G)$ appear empty. MT microtubule. $\times 30,000$

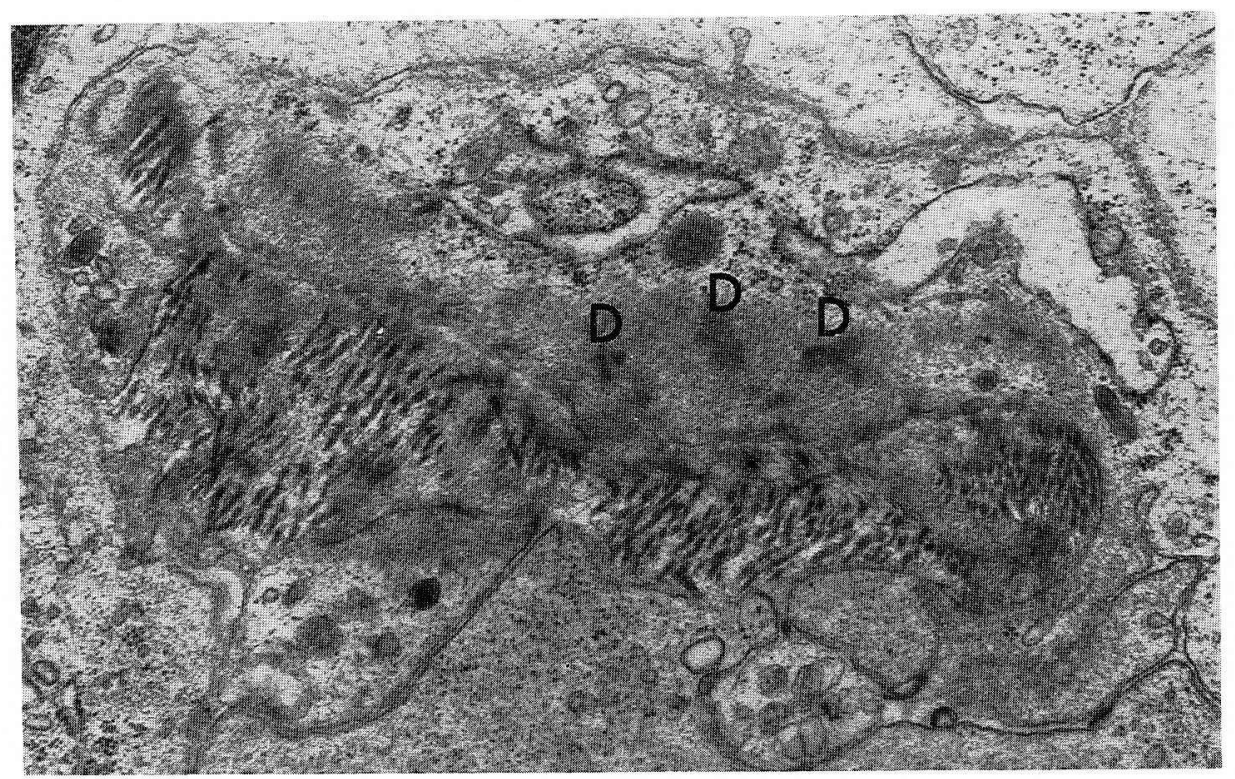

Fig. 9. Reticular cell processes in the white pulp. They have many filaments and several dense plaques $(D)$. In the extracellular reticulum, collagenous fibrils are prominent. $\quad \times 18,000$ 

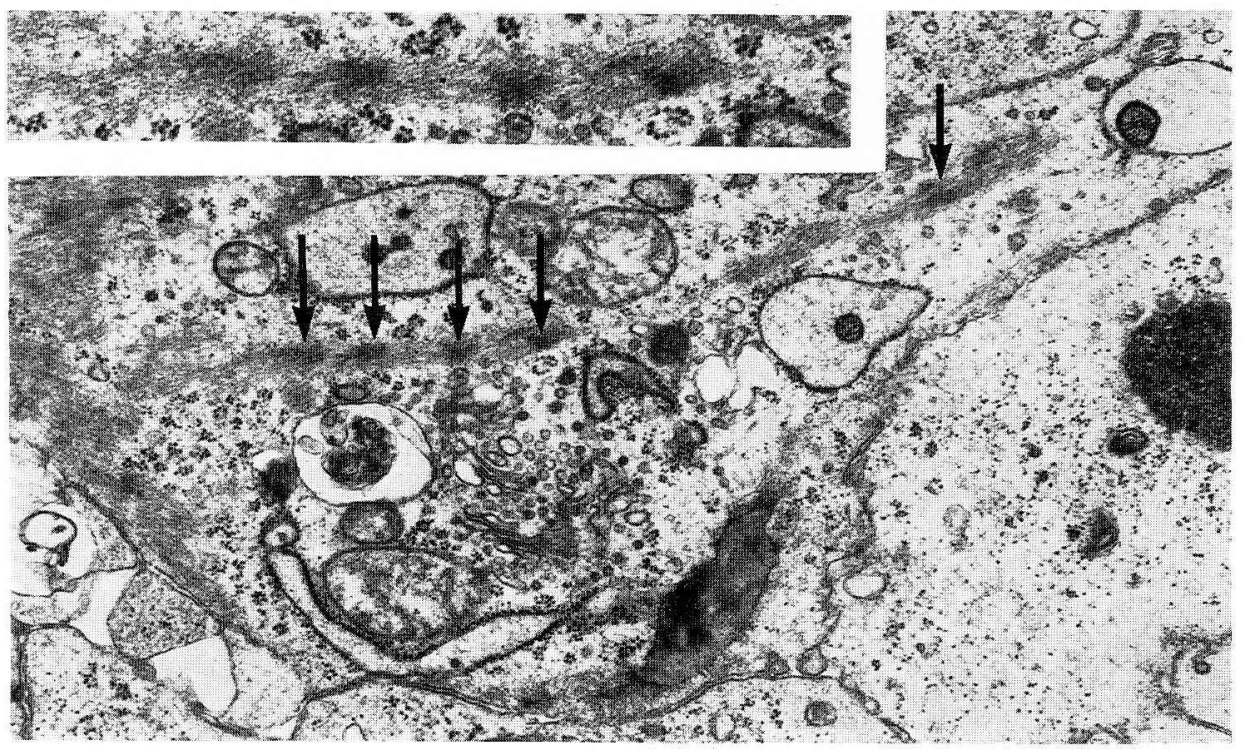

Fig. 10. Cytoplasmic process of the reticular cell in the white pulp. Dense bodies (arrows) are conspicuous in the bundles of filaments; some of them are arranged at irregular intervals. Granular endoplasmic reticulum shows tubular and vesicular forms containing a flocculent material. $\times 21,000$ Inset: Dense bodies are characterized by packing of filaments embedding in the amorphous material. $\times 50,000$

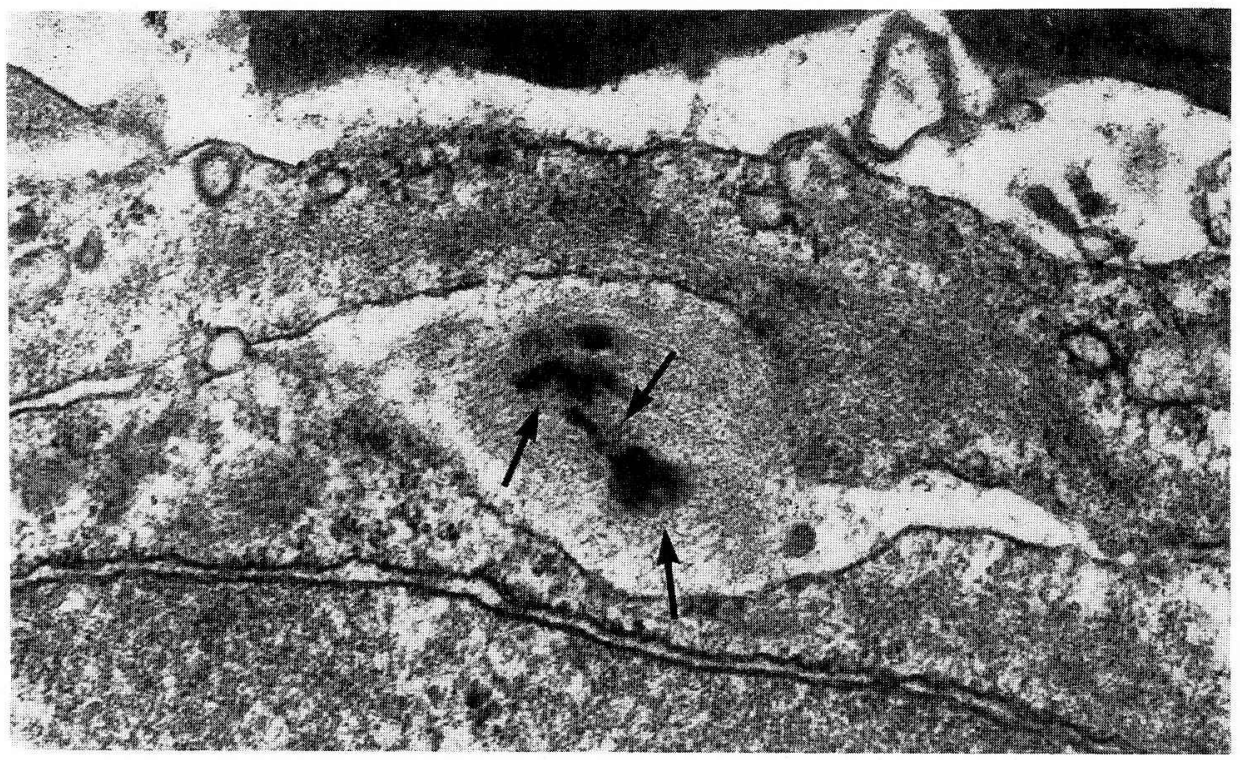

Fig. 11. Elastic fibers associated with microfibrils (arrow) in the extracellular reticulum were stained intensively when tannic acid fixation was used. $\times 54,000$ 
the filaments (Fig. 6, 9, 10). This appears identical to that in the smooth muscle cells. Although these filaments are found in all the cytoplasm randomly, even near the juxtanuclear region, the site of their most frequent occurrence is the cytoplasmic processes and beneath the plasma membranes where the extracellular reticular fibers are apposed. Development of the filamentous structure is less prominent in the reticular cells of the red pulp than in those of the white pulp and even of the marginal zone.

Pinocytotic vesicles are rarely found at the plasma membrane and no nerve ending apposing these cells are detected so far in the present study.

\section{Discussion}

As regards fibrogenesis by connective tissue cells, there are two controversial opinions on secretion of fibrous proteins. Some authors (REITH, 1968; FranK and FRANK, 1969; WEINSTOCK, 1972) support a secretion mechanism as in the exocrine cells in which protein molecules are transported from granular endoplasmic reticulum to the Golgi complex and released to the extracellular space (WARSHAWSKY et al., 1963; Caro and Palade, 1964; Redman et al., 1966; Jamieson and Palade, 1967, 1968a, b), while others suggest another pathway for fibrous precursors to the extracellular space (Rohr, 1965; Ross and Benditt, 1965, Cooper and Prockop, 1968, Salpeter, 1968). Either hypothesis lacks direct proof, but it is agreed that those cells which have a large amout of granular endoplasmic reticulum and a prominent Golgi complex represent the main source of fibrous proteins (PORTER and PAPPAS, 1959; KARRER, 1960; GoldBERG and GREEN, 1964; Ross and BenditT, 1964, 1965).

Since reticular cells seen in the rat spleen acquire a significant amount of granular endoplasmic reticulum and a well developed Golgi complex, it is reasonable to regard them as the chief cells producing the extracellular reticulum. That the Golgi vacuoles are empty and, in contrast, the lumen of granular endoplasmic reticulum contains a finely flocculent material in the reticular cell recalls the result of MERKER and STRuwE (1971) who described that the electron lucent material in the Golgi vacuoles and finely filamentous material in the cisterns of granular endoplasmic reticulum may be glycosamineglycane and fibrous protein respectively, and these materials would be secreted separately to the extarcellular space.

Whatever the secretion manner of the reticular cells may be, these are fibroblastic cells, and Simon and Pictet (1964), Moore et al. (1964) and Pictet et al. (1969) have called the splenic reticular cells "fibroblasts" because of their cytological similarities to the usual fibroblasts. However, they are somewhat different from typical fibroblasts in the following aspects; (1) reticular cells are so closely and limitedly associated with strands of the extracellular reticulum, (2) in the limited areas they have basal lamina-like materials which are not observed around fibroblasts, (3) bundles of fine filaments are abundant throughout the cytoplasm and among these bundles, dense bodies, and beneath the plasma membranes, hemidesmosomes are prominent.

WEISS (1963) first described the presence of intracytoplasmic filaments in the reticular cells but the functional significance of these filaments has not been wellunderstood. Pictet et al. (1969) proposed a view that they might be the cellular skeleton and are found in all cells which seem required to function as a supporting framework.

Cytoplasmic microfilaments have been described in a wide variety of non- 
muscular cell types, such as endothelial cells (CECio, 1967; MAJno et al., 1969), mesangial cells (YAMADA, 1955; FARQUHAR and PALADE, 1962), fibroblasts in the granulation tissue (MAJNo et al., 1971; GABBIANI et al., 1972), chondrogenic cells (IsHikAwA et al., 1969), peripheral nerve axon (YAMADA et al., 1970, 1971), phagocytic cells (WAGNER et al., 1971; REAVEN and AxLINE, 1973), interstitial cells of the lung (KAPANCI et al., 1974), migratory cells (Nachmias et al., 1970; Krawczyk, 1971; Spooner et al., 1971; McNutr et al., 1973) and embryonic cells being related to cytokinesis and morphogenesis (Schroeder, 1970; Spooner and Wessells, 1970; Wessells et al., 1971). Their thickness is varied ranging from 20 to $80 \AA$ in diameter. Though the functional significance of those filament containing cells has been variously interpreted, all these cells are known to have a contractibility or motility. Recent experimental studies have revealed that when cytochalasin B was applied to these cells, degenerative alterations occurred upon the filamentous structures and cell contraction ceased (Schroeder, 1970, 1972; Spooner and Wessells, 1970; Wrenn and Wessells, 1970; Wessells, et al., 1971; Yamada et al., 1971; Malech and Lentz, 1974). Thus, the filamentous structures have been regarded as the contractile elements in the cytoplasm, responsible for cell movement. In fact, in some instances, they are bound with heavy meromyosin to form arrowhead complexes or react with anti-actin sera, indicating that they represent actin filaments (IsHIKAwA et al., 1969; Pollard and Ito, 1970; Wessells et al., 1971; Becker, 1972; Comly, 1973; KAPANCI et al., 1974).

It seems reasonable to propose that the filaments found in the splenic reticular cells are contractile in nature, because of their morphological similarities to the filaments of the above mentioned motile cells. Moreover, it may be said that the reticular cells are partly differentiated to be muscular, as they possess small bundles of cytoplasmic filaments associated with dense bodies and hemidesmosomes. It is also of special interest that the plasma membrane associated with the hemidesmosome is always apposed with the extracellular reticulum to form the complexes which are analogous to those of smooth muscle cells (RHODIN, 1962) and endothelial cells (HoGAN and Fenney, 1963; Stehbens, 1966).

To sum up, the reticular cells of the spleen represent fibro-muscular cells, i.e., an intermediate form between the smooth muscle cell and the fibroblast.

The three-dimentional reticular tissue consisting of contractile cells and sustentacular reticulum not only supports the organ but also regulates the volumetric change of the vascular space of the splenic pulp co-operating with more specialized supportive and contractile functions of the fibroblasts and smooth muscle cells in the capsule and trabeculae. It is interesting to note that the fibro-muscular features of the reticular cells are more prominent in the white pulp, marginal zones and the red pulp. There is a passive pressure due to suction by the venous system and an active pressure due to the pouring of arterioles in the red pulp. However, in the white pulp, except for gross energy of muscle contraction in the central arteries and capsulotrabecular system, no pressure mechanism which manages blood flow is expected unless the reticular meshwork might efficiently be contractile. This seems to account for the distribution of more smooth muscle-like reticular cells in the splenic reticular tissue. There is the same distribution pattern of elastic fibers, namely, these fibers are located more in the white pulp and marginal zones. Occurrence of a set of contractile cells and back-stretching elastic fibers is reasonable as in the case of the usual smooth muscle tissue. 
Acknowledgement. The author wishes to express his sincere thanks to Prof. Susumu Iто (Department of Anatomy, Harvard Medical School) for his advice and reading this manuscript.

\section{ラットの脾臓内細網細胞の微細構造, とくにその筋-線維芽細胞様特徵について}

\section{斎 藤 紘 昭}

ラットの脾臓内の細網細胞は良く発達した粗面小胞体とゴルジ装置をもち, 細胞外性細 網の分泌に密に関与する線維芽細胞的な細胞であると思われる。同時に細網細胞ほ暗調小 体, 微細線維, 半デスモゾーム様装置を有し, 平滑筋に類似する点も観察される. この平 滑筋様の細網細胞は白脾髄, 辺縁帯, 赤脾䯣の順に多く存在する.

脾臓自体の体積の調節は被膜, 梁柱内の平滑筋の収縮によるとされているが, 平滑笳様 の細網細胞は, これらを助けて脾䯣内の血流の微細調節に関与するものと推測される.

\section{References}

Becker, C. G.: Demonstration of actomyosin in mesangial cells of renal gromerulus. Amer. J. Pathol. 66: 97-110 (1972).

Bloom, S. and D. W. Fawcett : A textbook of histology. 3rd. ed. W. B. Saunders Co., Philadelphia, 1968.

Bouteille, M., S. R. Kalifat and J. Delarue: Ultrastructural variations of nuclear bodies in human diseases. J. Ultrastr. Res. 19: 474-486 (1967).

Brooks, R. E. and B. W. Siegel : Nuclear bodies of normal and pathological human lymph node cells: An electron microscopic study. Blood 29: 269-275 (1967).

Büttner, D. W.: Sphaeridien mit kristalloiden Einschlüssen in den Zellkernen der Katzenmilz. Z. Zellforsch. 84: 304-310 (1968).

Caro, L. and G. F. Palade: Protein synthesis, storage and discharge in the pancreatic exocrine cell. An autoradiographic study. J. Cell Biol. 20: 473-495 (1964).

Cecio, A.: Ultrastructural features of cytofilaments in mammalian endothelial cells. Z. Zellforsch. 83: 40-48 (1967).

Comly, L. T.: Microfilaments in Choas carolinensis. Membrane association, distribution, and heavy meromyosin binding in the glycerinated cell. J. Cell Biol. 58: 230-237 (1973).

Cooper, G. W. and D. J. Prockop : Intracellular accumulation of tropocollagen and extrusion of collagen by embryonic cartilage cells. J. Cell Biol. 38: 523-537 (1968).

De Bruyn, P. P. H. and Y. Cho: Contractile structures in endothelial cells of splenic sinusoids. J. Ultrastr. Res. 49: 24-33 (1974).

Farquhar, M. G. and G. Palade : Functional evidence for the exsistence of a third cell type in the renal glomerulus. J. Cell Biol. 13: 55-87 (1962).

Frank, R. M. and P. Frank: Autoradiographie quantitative de l'ostéogenèse en microscopie électronique à l'aide de la proline tritiée. Z. Zellforsch. 99: 121-133 (1969).

Futaesaku, Y., V. Mizuhira and H. Nakamula: The new fixation method using tannic acid for electron microscopy and some observations of biological specimens. In: Histochemistry and cytochemistry (Proc. 4th Int. Congr. Histochem., Kyoto). 1972. (p. 155).

Gabbiani, G., B. J. Hirschel, G. B. Ryan, P. R. Statkov and G. Majno: Granulation tissue as a contractile organ. A study of structure and function. J. exp. Med. 135: 719-734 (1972).

Goldberg, B. and H. Green : An analysis of collagen secretion by established mouse fibroblast 
lines. J. Cell Biol. 22: 227-258 (1964).

Hogan, M. J. and L. Fenney : The ultrastructure of retinal vessels. III. Vascular glial relationships. J. Ultrastr. Res. 9: 47-64 (1963).

Ishikawa, H., R. Bischoff and H. Holtzer : Formation of arrowhead complexes with heavy meromyosin in a variety of cell types. J. Cell Biol. 43: 312-328 (1969).

Jamieson, J. D. and G. E. Palade : Intracellular transport of secretory proteins in the pancreatic exocrine cell. II. Transport to condensing vacuoles and zymogen granules. J. Cell Biol. 34: $597-615$ (1967).

III. Dissociation of intracellular transport from protein synthesis. J. Cell Biol. 39: 580-588 (1968a).

- Insracellular transport of secretory proteins in the pancreatic exocrine cell.

IV. Metabolic requirements. J. Cell Biol. 39: 589-603 (1968b).

Kapanci, Y., A. Assimacopoulos, C. Irle, A. Zwahlen and G. Gabbiani : "Contractile interstitial cells" in pulmonary alveolar septa: A possible regulator of ventilation/perfusion ratio? J. Cell Biol. 60: 375-392 (1974).

Karrer, H. E. : Electron microscope study of developing chick embryo aorta. J. Ultrastr. Res. 4: $420-454$ (1960).

Krawczyk, W. S.: A pattern of epidermal cell migration during wound healing. J. Cell Biol. 49: 247-263 (1971).

Majno, G., G. Gabbiani, J. Hirschel, G. B. Ryan and P. R. Statkon : Contraction of granulation tissue in vitro: similarity to smooth muscle. Science 173: 548-550 (1971).

Majno, G., S. M. Shea and M. Leventhal: Endothelial contraction induced by histamine type mediators. An electron microscopic study. J. Cell Biol. 42: 647-672 (1969).

Malech, H. L. and T. C. Lentz: Microfilaments in epidermal cancer cells. J. Cell Biol. 60: 473482 (1974).

McNutt, N. S., L.A. Culp and P. H. Black: Contract-inhibited revertant cell lines isolated from SV40-transformed cells. IV. Microfilament distribution and cell shape in untransformed, transformed, and revertant Balb/C 3T3 cells. J. Cell Biol. 56: 412-428 (1973).

Merker, H. J. and K. Struwe: Elektronenmikroskopische Untersuchungen zum Problem der Sekretion der bindegewebigen Interzellularsubstanz. Z. Zellforsch. 115: 212-225 (1971).

Moore, R. D., V. R. Mumaw and M. D. Schenberg: The structure of the spleen and its functional implications. Exp. mol. Pathol. 3: 31-50 (1964).

Nachmias, V. T., H. E. Huxley and D. Kessler: Electron microscope observations on actomyosin and actin preparations from Physarum polycephalum, and on their interaction with heavy meromysin subfragment I from muscle myosin. J. mol. Biol. 50 : 83-90 1970).

Pictet, R., L. Orci, W. G. Forssmann and L. Girardier: An electron microscope study of the perfusion-fixed spleen. Z. Zellforsch. 96: 372-399 (1969).

Pollard, T. D. and S. Ito : Cytoplasmic filaments of Amoeba proteus. I. The role of filaments in consistency changes and movement. J. Cell Biol. 46: 267-289 (1970).

Porter, K. R. and G. D. Pappas : Collagen formation by fibroblasts of chick embryo dermis. J. biophys. biochem. Cytol. 5: 153-166 (1959).

Reaven, E. P. and S. G. Axline: Subplasmalemmal microfilaments and microtubules in resting and phagocytizing cultivated macrophages. J. Cell Biol. 59: 12-27 (1973).

Redman, C. M., P. Siekevitz and G. E. Palade: Synthesis and transfer of amylase in pigion pancreatic microsomes. J. biophys. biochem. Cytol. 241: 1150-1158 (1966).

Reith, E. J.: Collagen formation in developing molar teeth of eats. J. Ultrastr. Res. 21 : 383-414 (1968).

Rhodin, J. A. G.: Fine structure of vascular walls in mammals: with special reference to smooth muscle component. Physiol. Rev. 42: 48-81 (1962).

Rohr, H.: Die Kollagensynthese in ihrer Beziehung zur submikroskopischen Struktur des Osteo- 
blasten. Virchows Arch. pathol. Anat. physiol. 338: 342-354 (1965).

Ross, R. and E. P. Benditt : Wound healing and collagen formation. IV. Distortion of ribosomal patterns of fibroblasts in scurvy. J. Cell Biol. 22: 365-389 (1964).

- : Wound healing and collagen formation. V. Quantitative electron microscope radioautographic observation of proline $-\mathrm{H}^{3}$ utilization by fibroblasts. J. Cell Biol. 27: 83-106 (1965).

Salpeter, M. M.: ${ }^{3} \mathrm{H}$-proline incorporation into cartilage: EM autoradiographic observations. J. Morphol. 124: 387-422 (1968).

Schroeder, T. E.: The contractile ring. I. Fine structure of dividing mammalian (HeLa) cells and the effects of cytochalasin B. Z. Zellforsch. 109: 431-449 (1970).

-: The contractile ring. II. Determining its brief existence, volumetric changes, and vital role in cleavage Arbacia eggs. J. Cell Biol. 53: 419-434 (1972).

Simon, G. and R. Pictet : Etude au microscope electronique des sinus spleniques et des cordons de Billroth chez le rat. Acta anat. 57: 163-171 (1964).

Spooner, B. S. and N. K. Wessells : Effects of Cytochalasin B upon microfilaments involved in morphogenesis of salivary epithelium. Proc. Nat. Acad. Sci. U.S.A. 66: 360-364 (1970).

Spooner, B. S., K. M. Yamada and N. K. Wessells : Microfilaments and cell locomotion. J. Cell Biol. 49: 595-613 (1971).

Stehbens, W. E. : The basal attachment of endothelial cells. J. Ultrastr. Res. 15: 389-399 (1966).

Venable, J. H. and R. Cogceshall : A simplified lead citrate stain for use in electron microscopy. J. Cell Biol. 2: 407-408 (1965).

Warshawsky, H., C. P. Leblond and B. Droz: Synthesis and migration of proteins in the cells of the exocrine pancreas as revealed by the specific activity determination from radioautographs. J. Cell Biol. 16: 1-23 (1963).

Watson, M. : Staining of tissue sections for electron microscopy with heavy metals. J. biophys. biochem. Cytol. 4: 475-478 (1958).

Weinstock, M.: Collagen formation: Observations on its intracellular packaging and transport. Z. Zellforsch. 129: 455-470 (1972).

Weiss, L.: The structure of intermediate vascular pathways in the spleen of rabbits. Amer. J. Anat. 113: 51-92 (1963).

Wessells, N. K., B. S. Spooner, J. F. Ash, M. O. Bradley, M. A. Ludvena, E. L. Taylor, J. T. Wrenn and K. M. Yamada: Microfilaments in cellular and developmental processes. Science 171 : 135-143 (1971).

Wrenn, J. T. and N. K. Wessells : Cytochalasin B: Effects upon microfilaments involved in morphogenesis of estrogen-induced glands of oviduct. Proc. Nat. Acad. Sci. U.S.A. 66: 904908 (1970).

Yamada, E.: The fine structure of the renal glomerulus of the mouse. J. biophys. biochem. Cytol. 1: 551-556 (1955).

Yamada, K. M., B. S. Spooner and N. K. Wessells : Axon growth: Role of microfilaments and microtubules. Proc. Nat. Acad. Sci. U.S.A. 66: 1206-1212 (1970).

Biol. 49: 614-635 (1971).

斎藤紘昭

于232 横浜市浦舟町 $2-33$

横浜市立大学医学部

第一解剖学教室
Dr. Hiroaki SaIto

Department of Anatomy

Yokohama City University School of Medicine

Yokohama, 232 Japan 